\title{
THE INDONESIAN NAVY EFFORT IN EMPOWERING FISHERMEN AS A NATIONAL DEFENSE RESERVE COMPONENT
}

\author{
Setiawan Yoga Arief, Magister Student \\ Fanani Z., Said Abdullah, Lecturers \\ University of Brawijaya, Indonesia \\ *E-mail: pakmakinpps@gmail.com
}

\begin{abstract}
This study aims to analyze the efforts of the Navy in empowering fishermen as a national defense reserve component. This study uses a qualitative descriptive approach, with the research site located at Navy Basecamp V Surabaya. Data collection is done by interview, observation and documentation study, while the analysis of research data using the inductive data analysis model according to Milles \& Michael. The results showed that so far the efforts made by the Indonesian Navy in empowering fishermen were still limited to fishing counseling, sea law socialization and regional social activities. Lantamal V Surabaya needs to carry out concrete efforts in order to prepare fishermen as a national defense reserve component. Therefore, it is necessary to develop a pattern of empowering fishermen to become agents of national defense, especially in terms of carrying out surveillance functions in support of the tasks of the Navy in the defense of sea dimensions.
\end{abstract}

\section{KEY WORDS}

Indonesian Navy, fishermen empowerment, national defense reserve component.

The Act Number 3 of 2002 about National Defense states that the Indonesian National Army (TNI) is a major component in national defense. The Indonesian National Armed Forces (TNI) consists of the Army, Navy and Air Force who carry out their duties in dimensions or in combination under the leadership of the TNI Commander. Article 9 of Act Number 34 of 2004 about TNI stated that one of the tasks that must be carried out by the Navy was to carry out empowerment of the sea defense area. This is part of the Military Operations Other Than War activity, which is assisting the government in securing shipping and aviation against piracy, piracy and smuggling.

Efforts to strengthen the main components are certainly very much needed support from other components in order to strengthen the main components as the backbone of Indonesia's defense. In another explanation of the defense law, it is stated that the reserve component is the National Resources prepared to be mobilized and used to enlarge and strengthen the main component. National Resources itself consists of Human Resources, Natural Resources and Artificial Resources. Indonesia implements the Universal People's Defense System (Sishanrata) as stipulated in Article 27 paragraph (3) of the 1945 Constitution and Article 30 paragraph (1), in which every citizen has the rights and obligations in the country's defense efforts. Sishanrata is a defense system that involves all national resources prepared early by the government and is carried out in a total, integrated, directed and sustainable manner to uphold the country's sovereignty, maintain territorial integrity, and secure the entire nation from all forms of threats.

In article 3 of the Republic of Indonesia Constitution Number 23 of 2019 about Management of National Resources for National Defense it is explained that the Management of National Resources for National Defense aims to transform Human Resources, Natural Resources, and Artificial Resources as well as National Facilities and Infrastructure into National Defense forces that are ready to be used for the benefit of National Defense. Management of National Resources for National Defense is carried out through the defense of the State Defense, Structuring of supporting components, Formation of Reserve Components, Strengthening of Main Components, and Mobilization and Demobilization. 
Based on the legal basis that has been described above, and by reflecting on the magnitude of the existing maritime threats, it is necessary to establish a pattern of formation of reserve components, structuring supporting components, mobilization and demobilization processes in the context of strengthening the main components especially the defense of the sea dimension that is the Indonesian Navy.

Fishermen are one part of the elements of the community that daily rely on sea products to support their lives. Some fishermen are still classified as low income groups. In catching fish, they still use relatively small boats that use temple engines. This results in a limited range to the fishing grounds. This has implications for the income they earn less to meet their daily needs. The empowerment of fishermen is one of the right steps that need to be carried out by the government and related agencies and supported by the active role of fishermen to further develop the potential of the fishermen to improve the lives of fishermen themselves and also for the local government is also a form of fishermen preparation activities as national defense reserve component.

Fishermen are part of Human Resources as a reserve component in national defense. Therefore, in the context of national defense, fishermen can be used as an extension of the Navy's Navy and assist the duties of the Navy's Navy in addition to the war given the limited number and capabilities of the Navy's warships faced with the vast Indonesian sea. This is important considering that some Navy ships cannot reach inland waters and need help from several other supporting elements. Haribowo (2010) explains that the number of Navy ships has not been able to reach the entire territorial waters of Indonesia. Therefore, besides fishing, fishermen can be empowered to carry out roles that can support the Indonesian Navy's main tasks in carrying out sea-defense tasks. To realize this, of course, there needs to be concrete attention and action from the government and the authorities in the form of counseling, education and other educational activities in the context of preparing fishermen as a reserve component in the defense of the sea dimension in the sea territory of the Unitary State of the Republic of Indonesia.

In a study which entitled The Influence of Maritime Empowerment and Fishermen Training Against Coastal Community Welfare In Order to Optimize Defense Strategies in Cemis Village in Cemandi, Sidoarjo Regency (2018), Sadaraianto revealed that the steps taken by the Maritime Potential Office (Dispotmar) Surabaya as an implementing element the development of maritime potential in Sidoarjo which is an area under the working area of Lantamal V Surabaya, has not been running optimally. Coordination meetings conducted in the context of determining steps for empowering maritime areas are only discussed within the Navy and do not involve relevant stakeholders so that there is often a lack of readiness in supporting these efforts so that the targets of the formulation of problems and strategies cannot be achieved.

As a result of the vast Indonesian sea area, there are several areas that are difficult to reach by law enforcement officers at sea, both from the Navy and other stakeholders who have the duty and responsibility to maintain security at sea. The narrow and shallow waters make one of the obstacles faced by the Navy to reach remote islands using Navy-owned warships. These gaps are used by many persons not responsible for carrying out activities against the law that can harm the state and nation of Indonesia. Besides that, the escalation in escalation and transfer of issues in an area can allow concentration of power which has implications for the presence of a law enforcement presence at one point, so that it gives space for criminal elements to carry out their actions in the abandoned area.

In this case, the role of fishermen who have higher mobility and understand well the character of the sea area of an area becomes very important to be empowered to support the basic tasks of the Navy in the defense of the sea dimension. The fishermen can be used as an extension of the Navy wherever they carry out fishing. The fishermen can report all forms of events that they find when carrying out fishing to the KRI elements of the Navy or other Stakeholders so as to be able to ward off all forms of threats in the form of safety, security and defense at sea. 


\section{MATERIALS AND METHODS OF RESEARCH}

This research is a qualitative descriptive study, to describe or paint research objects based on facts that appear or as they are. Primary data is a source of research data obtained directly from the original source (without going through intermediaries), in the form of individual or group individual (group) information, observations, and test results. While secondary data is a source that does not directly provide data to data collectors, for example through other people or through document studies.

The determination of informants is done by purposive sampling by looking at the capacity, experience and abilities in their fields that represent several levels of interest or function related to the problems that exist in the work area of V Lantamal Surabaya. The research informants consisted of 1 (one) Navy TNI middle officer currently serving at the Surabaya Lantamal V Maritime Potential, 3 (three) Navy TNI officers who had conducted sea security operations in the Lantamal V Surabaya area and 1 (one) person from the Surabaya Maritime and Fisheries Service (DKP) which is one of the stakeholders responsible for managing fishermen in the Surabaya area, 1 (one) fisherman in the Surabaya area.

Data collection in this study included in-depth interviews, participatory observation and documentation. In interviews, parties who are competent and directly related to the object of research are asked for information in accordance with the interview guidelines so that the information / data to be obtained can be focused and effective and efficient. In carrying out participatory observations, researchers plunge directly into the object of research to see, hear and obtain and record data on what researchers find during conducting research as a discussion with informants. Documentation studies are carried out to strengthen the studies carried out previously, by searching for information through how to study textbooks, literature and scientific papers, as well as documents relevant to research problems.

This data collection process is carried out continuously. After the data is collected, the researcher carries out data analysis to look for tentative meanings and then is constantly reviewed based on the data obtained later. Next, the researcher verifies the information to get the truth from the data that has been obtained by triangulation. Next, the researcher makes a report based on the notes or records obtained. Finally, the researcher will ask deepening questions to further research until the point of saturation of data and research problems can be answered.

The data analysis technique used in this research is a descriptive technique that is carried out through three activity streams, such as reduction, data presentation and conclusion drawing (Miles and Michael 1992). Data reduction is done by selecting, focusing, simplifying, abstracting and transforming rough data into written notes in the field. Further data presentation is carried out with descriptive descriptions to compile complex information in a systematic form so that it is more selective, to obtain meaningful patterns, and to provide possibilities for drawing conclusions and decision making. Finally, in drawing conclusions researchers formulate the meaning of the data that has been presented. The conclusions drawn from the field data continue to be tested for truth, robustness and compatibility during the study so that they really get an objective conclusion and guaranteed validity.

This descriptive qualitative approach will help in knowing and analyzing field conditions and offering ideas related to further development efforts. Researchers view the role of fishermen as very important in supporting the basic tasks of the Navy in carrying out the task of national defense. With the limitations of the ships owned, the Indonesian Navy has not been able to reach the entire Indonesian sea area, especially in the interior. Therefore, fishermen can be used as an extension of the Indonesian Navy that can provide information about events and problems that need to be resolved when carrying out fishing activities, as information about potential threats to the defense of Indonesian.

\section{RESULTS AND DISCUSSION}

Fishermen in the Surabaya area are included as coastal fishermen; this is because the fishermen only catching for no more than 12 nautical miles from the shoreline. These 
fishermen catch fish using simple and natural fishing gear. Besides these ships do not have complete safety standards. These fishermen have a very large risk of danger, considering that they catch fish in the waters of the West Surabaya Shipping Line (APBS) and East Surabaya Shipping Line (APTS) where there are many large ships passing by. Especially if the fishermen carry out fishing at night, the risk of accidents is very large because the vessels that pass are very large and the fishing boats are very small in size so it is difficult to see in foggy weather or at night. Fish vessels commonly used to catch fish often get into water when passing large vessels passing in the waters of APBS and APTS.

With a small boat and limited sailing capability, it is certainly stated that fish which can be caught by fishermen are still far from expectations, while their lives are highly dependent on the catch of fish they catch every day. With such fishing equipment, the catches obtained are still far from expected.

The fishermen generate income of 100,000 to 125,000 per day when the weather is good, and only get 50,000 to 60,000 when the weather is not good and if the weather is bad the fishermen don't dare to go to sea and that means they don't get income at that time. Fish obtained by Surabaya fishermen are mixed fish species such as shrimp, crabs, mullets, groupers and shellfish. The catch is then sold to collectors for resale. The fishermen are very dependent on the fish they catch every day, so that if they do not go to sea, the fishermen have no income because they have no other work.

They fulfill the void of time by carrying out ship maintenance and repairing fishing gear that starts to break after being used for fishing before. The fishermen do not have side jobs but only catch fish in the sea. This affects in the economic life of the fishing community is still very lacking. Fishermen families must arrange for their family's daily needs and also pay for schooling for their children who are still studying. Economic conditions like this result in the average fishermen's children are only able to take education up to the level of SMA / SMK or equivalent.

The phenomena and facts described above show that the condition of fishermen in Surabaya is still quite alarming. The condition of the fishing communities is caused because they depend on their catch for their lives. Their catch is not optimal because of the equipment and equipment they have are still traditional. This condition certainly needs special attention from the local government to prosper the lives of the fishing communities in the context of realizing social justice for all the people of Indonesia.

In Act Number 3 of 2002 concerning national defense, it has been explained that the $\mathrm{TNI}$ is the main force in national defense. This was then spelled out in Law Number 34 of 2004 concerning the main tasks of the TNI in carrying out national defense efforts. Then Law number 34 of 2004 About TNI article 7 paragraph (2) letter b number 8 also explains that the $\mathrm{TNI}$ has the task of empowering the defense area and its supporting forces early in accordance with the universal defense system. As the country's main defense tool, the TNI has duties and responsibilities in empowering defense areas and various supporting components in it.

Act No. 23 of 2019 concerning the use of National Resources in national defense is increasingly clarifying and can be used as a strong legal basis for the TNI in carrying out the development, preparation and empowerment of National Resources in efforts to empower the country. The Navy which is part of the TNI also has the same task, especially in the field of marine dimensions. The Navy as a means of national defense at sea has the task of empowering the region and maritime potential for matters of national defense.

Lantamal V Surabaya is one of the bases held by the Indonesian Navy under the command of Koarmada II. As one of the bases owned by the Navy, Lantamal V Surabaya has the task of carrying out the main tasks of the Navy and the TNI is no exception carrying out coaching, empowerment and development of maritime potential in the Surabaya region. In the organizational structure of Lantamal V Surabaya itself, Danlantamal as the leader of Lantamal has the Maritime Potential Assistant (Aspotmar) who has the task of assisting Danlantamal in carrying out the tasks of coaching, supervising and empowering maritime potential in the working area of Lantamal V Surabaya. 
From now on the Surabaya V Lantamal has carried out several activities aimed at carrying out empowerment and coaching of coastal communities in the Surabaya V Lantamal working area. The programs implemented by Surabaya $\mathrm{V}$ Lantamal in coastal communities are incorporated in the Coastal Villages Development Program (Bindesir). Activities that have been carried out by V Surabaya include; (1) Mass free treatment of coastal communities, (2) Conduct counseling about the dangers of Narcotics to coastal communities, (3) Assistance with renovation of places of worship in coastal villages, (4) Holding mass circumcision events, (5) Planting Mangroves and (6) Character building for high school students in the Surabaya city area.

From some of the above activities, the activities that have been carried out by Lantamal V Surabaya are to empower fishermen in terms of economic and social aspects. Not yet found the activities that are empowering that lead in the preparation of fishermen as a reserve component in national defense. These things should also be done by naval potential maritime service (Dispotmar) Lantamal V Surabaya, considering that fishermen are one of the maritime potentials who have great potential in helping the Navy's day duty. Fishermen can be used as an extension of the eyes and ears of a patrol boat belonging to the Navy to participate in assisting surveillance activities considering that patrol ships owned by the Navy, have not been able to reach all existing sea areas. Therefore the role of fishermen is also very important in the national defense business, especially as a reserve component.

Based on the research data, there are some constraints faced by Lantamal V Surabaya in implementing empowerment of fishermen, namely 1) Not yet fulfilled the needs of Potmar personnel in Lantamal V, so that the planned program cannot be fully implemented. 2) Communication between Lantamal V Surabaya and fishermen groups in the Surabaya area has not yet been realized. That is because there were no found fishermen guided by Surabaya V Lantamal. 3) Lantamal V Surabaya has not cooperated with related agencies to carry out fishermen empowerment.

This was also stated by Sadarianto (2018) that the Lantamal V Maritime Potential Service Office in Surabaya as an implementing unit in the empowerment of maritime areas in the region was still not optimal and did not achieve its targets. That is because one of them is because the planning of extension activities to fishermen is only discussed within the scope of the Navy only without involving existing stakeholders. The constraints mentioned above that ultimately resulted in not yet realized the activities of empowering fishermen by Surabaya V Lantamal.

According to Sumodiningrat in Dani Iskandar (2017) there are stages that need to be carried out in carrying out community empowerment, these stages such as: 1) The stage of awareness and formation of conscious and caring behavior, these things can foster a sense and willingness to increase the ability and capacity of itself. 2) The transformation stage of work ability is open to insight knowledge, skills, in order to open up insights and give knowledge of basic skills so that they can take a role in development. 3) Capacity building phase, at this stage the empowerment must improve intellectual abilities, skills, skills so that innovative initiatives and abilities are formed to deliver independence.

Reflecting on the role of Surabaya V Lantamal in empowering fishermen carried out so far, as well as seeing various obstacles in the empowerment of fishermen activities by Surabaya V Lantamal, then there are some important things that must be done by Surabaya $\checkmark$ Lantamal in the future for empowering fishermen as a component of state reserves.

Provide Infrastructure for Fishermen for Fishing Activity. In the Basic Need theory put forward by Abraham Maslow (1908-1970), it has been stated that to motivate a person or group, what needs to be fulfilled first is its physiological needs. Physiological needs are basic needs that must be met first before carrying out the planned activities. In this case, researchers see Surabaya V Lantamal needs to carry out assistance in the form of ships to catch fish, fishing gear and modern and complete safety equipment. This requirement is absolutely needed by fishermen, because it is a set that is highly needed by fishermen in fishing.

Carry out a Marine Safety Patrol. After fulfilling the physiological needs or basic needs of fishermen, Lantamal V Surabaya needs to provide a sense of security for fishermen in 
carrying out fishing. This provision of security can be realized by carrying out Marine Safety Patrol activities around fishing areas carried out by fishermen. This can provide security and comfort to the fishermen so that the fishermen will continue to go fishing to carry out fishing.

Provide National Defense Education to Fishermen. National defense education is essentially one form of action to realize awareness of love for the motherland. The 1945 Constitution article 27 paragraph (3) and article 30 paragraph (1) disclose that all Indonesian citizens have the rights and obligations in carrying out foreign affairs. According to Widodo (2011) Defending the country is the attitude and actions of citizens based on a sense of patriotism, national and state awareness, Pancasila (Five pillars of Indonesia) beliefs as an ideology of the nation and state, willingness to sacrifice the survival of the nation and state. According to Soepandi (2018) National defense education can have a real impact on the nation and nation of Indonesia. The importance of international education to be given to fishermen is to foster a sense of love for the motherland so that fishermen will not take actions that are not detrimental to the nation and state.

In the act of fishing carried out by fishermen associated with state defense education, the actual manifestations of state defense that can be carried out by fishermen are as follows 1) Fishermen will participate in preserving all forms of Marine Resources available by carrying out fishing methods or methods true like not using sea bombs, not using trawlers or ways that can damage the existing marine ecosystem. 2) Fishermen will participate in monitoring the management of the existing maritime potential. 3) Fishermen will participate in national defense efforts as a backup component if needed at any time. From some of the above it can be seen that the need for state defense education to fishermen as one of the efforts to empower fishermen as a backup component in national defense.

Provision of Work Ability to Fishermen. According to Winardi (2007) Work ability is the ability that must be possessed by someone to foster and foster initiative in work. Meanwhile according to Ni Luh Sekartini (2016) ability is the potential of people to carry out their duties or work. Work ability is the ability possessed by an individual in completing tasks given to him, and that ability is stable or permanent.

This work ability needs to be given to fishermen considering that fishermen carry out fishing in a long time, even up to three months. Therefore, the fishermen need to have a good ability, especially in order to survive at sea. Lack of ability of fishermen when carrying out fishing is an obstacle when operating. Other obstacles that can be faced by the fishermen when carrying out fishing can be in the form of bad weather, engine damage, declining health conditions and other problems.

To deal with the problems that are found and survive while fishing, fishermen need to have the ability and skills to overcome these problems. This is of course to optimize and maximize the catch of fishermen. Some basic abilities that must be possessed by fishermen in carrying out fishing including: 1) Maritime skills (navigation, communication and engineering); 2) Work safety; 3) Sea Survival or the ability to survive at sea; 4) fishing skills, and 5) marine surveillance skills. The above skills absolutely must be possessed by a sailor in carrying out the voyage, especially to fishermen when carrying out fishing.

The Provision of Intellectual Capability to Fishermen. According to Goleman (2002) Intellectual ability is the ability to recognize yourself, motivate yourself and the ability to manage emotions in relationships with others. Intellectual ability is how an individual is able to carry out mental activities and think clearly based on science (Sari, 2017; Sentia, 2017). Provision of intellectual abilities can be interpreted as education given to individuals or groups that aim to improve individual or group knowledge.

In empowering fishermen, of course the fishermen need to be equipped with some knowledge that aims to increase the insight and knowledge of fishermen in various ways. Associated in the activities of fishermen who carry out fishing and preparation of fishermen as one of the reserve components in national defense, fishermen need to gain some knowledge as follows: 1) Dissemination of the Law on maritime affairs and fisheries. This needs to be given to add insight and knowledge of the fishermen, especially to find out the prohibitions that must not be implemented when carrying out fishing. 2) Dissemination of the Law on the Environment. This activity needs to be carried out so that later fishermen can 
also actively participate in participating in preserving the marine ecosystem. 3) Dissemination of Narcotics, Psychotropic and other illegal drugs. This activity is one of the preventive activities to prevent the spread and use of drugs. 4) Basic intelligence. This knowledge can be used as a provision for fishermen when carrying out fishing as well as for participation in the role of ocean surveillance of all forms of crime in the ocean.

Giving Award to Fishermen. After fulfilling physiological needs, a sense of security and attention, then something that needs to be done next to make fishermen as one of the reserve components in the national defense is to give appreciation to fishermen. According to the Big Indonesian Dictionary, an award can be interpreted as a tribute given on the basis of the dedication that has been carried out for a matter. From some of the above understanding, it can be concluded that the award is a tribute and appreciation given to someone for their services and dedication for the progress of the organization or group.

According to Usman (2000) Award as a method of learning has several forms such as verbal and non-verbal. Verbal awards are awards given by giving good words, which can encourage the spirit to continue to do the best for the recipient of the award. Meanwhile, the Non Verbal Award is in the form of mimic and body movements, by showing concern, giving honors in the form of certificates or letters and giving aid and compensation funds.

Meanwhile, the aim of awarding is to further develop and optimize intrinsic and extrinsic motivations in the sense that fishermen need to be rewarded for their duties and services so that fishermen continue to have an interest in fishing and fishing at sea.

Build partnerships with related stakeholders for empowering fishermen. Fishermen empowerment is intended as an effort to maximize the role of fishermen. Fishermen are the spearhead for the government in fisheries activities. But the fact is that there are still many fishermen who live at the poverty level. The lack of knowledge that possessed by fishermen in carrying out fishing results in not maximizing the catch of fish which results in a lack of income for the fishermen, while fishermen or other coastal communities purely depend on their lives from marine products. If the fishermen have good knowledge and methods of fishing, of course the fish catch can also increase. This not only results in an increase in the income of the fishermen, but also can increase income for the region. Certainly increasing regional income can increase and strengthen economic resilience in the region.

Although they do not go participate directly in wars or battles, it does not mean that fishermen do not have a role in national defense efforts. In terms of antidote threats, of course the role of fishermen is very large. The current number of Indonesian Navy ships has not been able to reach the entire sea area owned by Indonesia. Aside from that, the ships also have technical limitations so that they cannot reach all territorial waters when conducting sea security patrols. This in turn gives space for the perpetrators of criminal acts to carry out their actions. Some informants in this study explained that they often get important information from fishermen relating to violations at sea which escapes the supervision of law enforcement officers. Of course it is very detrimental because law enforcement officials have a delay in obtaining such information which results in no action against the violation.

Based on Act No. 23 of 2019 concerning the use of National Resources for national defense, it has been explained that National Resources can be used in national defense efforts. The role of National Resources occupies a position as a reserve component which is at any time ready to be used to support military force which is a major component of defense. To create a backup component that is strong and ready to be used to support the main component, certainly it is necessary to carry out efforts that are carried out in real so that the backup component can be ready for use when needed. Fishermen are part of the community and the community is part of Human Resources which is one of the reserve components in national defense.

Therefore, fishermen need to get the attention of the Indonesian Navy by carrying out continuous training to fishermen, so that fishermen can be used as a backup component and assist in the task of national defense, especially the sea dimension. These efforts certainly cannot be carried out on their own; the Navy needs to coordinate with relevant parties such as the local Fisheries Service, Water and Air Police (Polairud) and with fishermen so that the effort to establish fishermen as a component of the country's defense reserve can be realized. 
The link in national defense, fishermen can be used as an extension of the eyes and ears of law enforcement officers at sea, especially the Navy. Areas where there is no law enforcement presence can be filled by fishermen as intelligence agents who always provide information on the situation and conditions in the local area to the authorities. If the Indonesian Navy, which is a major component of national defense, can engage or invite relevant stakeholders, then national defense, especially the sea dimension at both the main and reserve levels, will be strong and ready to oversee national defense.

\section{CONCLUSION}

Indonesia has a large number of sea and abundant wealth in it. This wealth brings several threats that can be detrimental to Indonesia. Incoming threats can be military threats or non-military threats. To ward off all these threats a strong Navy is needed and is supported by a reserve component in it that is trained and prepared when needed. The number of elements of the Indonesian Navy when compared to the size of the Indonesian seas still does not reach all sectors of the Indonesian sea area. Therefore, the Navy needs to get support from various elements in order to strengthen the defense of the sea dimension. Fishermen can be used as one of the reserve components in defense, especially coastal or marine defense. The role given by fishermen in assisting the defense task is to be an extension of the eyes and ears of the Navy ship in order to carry out surveillance of the marine sector that cannot yet be reached by the Navy ship. To prepare fishermen in carrying out support in national defense, efforts should be made to empower fishermen so that these fishermen are ready to be used whenever needed in the national defense effort, especially in the defense of the sea dimension.

\section{ACKNOWLEDGEMENTS}

The researchers express gratitude to the leaders and staff of the Surabaya V Lantamal, Surabaya Fisheries and Maritime Services and the fishermen as informants who provided data and information to the researchers to compile this article.

\section{REFERENCES}

1. Biddle, B.J and Thomas, E.J, 1966. Role Theory: Concept and Research. New York: Wiley.

2. Buerger, C, 2015. What is Maritime Security? Forthcoming in Marine Policy. Department of Politics and International Relations Cardiff University.

3. Friedmann, J., 1987. Planning in The Public Domain: From Knowledge to Action. New Jersey: Princeton University Press.

4. Goleman, D., 2002. Kecerdasan Emosional. Jakarta: PT. Gramedia Pustaka. Utama

5. Hafid, S., 2014. Teori Perencanaan. In Dasar-dasar Teori Perencanaan. Jakarta: Universitas Terbuka.

6. Iskandar, D., 2017. Pemberdayaan Masyarakat Dalam Bidang Pertanian Oleh Lembaga Pemberdayaan Masyarakat Di Desa Jadimulya Kecamatan Langkaplancar Kabupaten Pangandaran. Jurnal IImiah IImu Pemerintahan. 3.1: 124-133.

7. Kartika, S.D., 2014. Keamanan Maritim dari Aspek Regulasi dan Penegakan Hukum. Jurnal Negara Hukum. 5.2: 67-77.

8. Miles, M.B., Huberman, A.M., Saldana, J., 1992. Qualitative Data Analysis: A Methods Sourcebook, Edition 3, USA: Sage Publication.

9. Sadarianto, S., Anwar, S., Purwanto, P., 2018. Pengaruh Pemberdayaan Wilayah Maritim dan Pelatihan Nelayan Terhadap Kesejahteraan Masyarakat Pesisir Dalam Rangka Mengoptimalkan Strategi Pertahanan di Desa Gisik Cemandi Kabupaten Sidoarjo. Jurnal Strategi Pertahanan Semesta. 4.3. 
10. Sekartini, N.L., 2016. Pengaruh Kemampuan Kerja, Disiplin Kerja, Motivasi Kerja Terhadap Kepuasan Kerja Dan Kinerja Karyawan Administrasi Universitas Warmadewa. Jurnal Ekonomi dan Bisnis JAGADITHA. 3.2.

11. Soekanto, S., 2007. Sosiologi, Suatu Pengantar. Jakarta: Rajawali Press.

12. Soepandi (2018) Kris Wijoyo Soepandi, W., Farid, M. 2018. Konsep Bela Negara Dalam Perspektif Ketahanan Nasional. Jurnal Hukum dan Pembangunan. 48.3: 448-460.

13. Suhardono, E. 1994. Teori Peran: Konsep, Derivasi dan Implikasinya. Jakarta: Gramedia.

14. Rapika, S. \& Sari, A.P., 2017. Pengaruh Kepribadian Dan Kemampuan Intelektual Terhadap Kompetensi Guru Di Smkn 3 Kota Bengkulu. Jurnal Management Insigth. 12. 2: 64-76.

15. Wibowo (2017). Managemen Kinerja. Jakarta: Rajawali Press.

16. Widodo, S., 2011. Implementasi Bela Negara Untuk Mewujudkan Nasionalisme. Jurnal Civis. 1.1: 19-30.

17. Winardi. 2007. Managemen Prilaku Organisasi. Jakarta: Kencana. 